BBA 75 II9

\title{
EFFECTS OF NON-METABOLIZABLE ANALOGS ON THE DISTRIBUTION OF AMINO ACIDS IN THE RAT*
}

HALVOR N. CHRISTENSEN AND ANDREA M. CLLLEN

Department of Biological Chemistry, The University of Michigan, Ann Arbor, Mich. (U.S.A.)

(Received September I8th, I967)

\section{SUMMARY}

The injection into the normal or adrenalectomized rat of $\alpha$-aminoisobutyric acid caused the loss from the liver within $2 \mathrm{~h}$ of $\mathrm{I} / 3$ to $2 / 3$ of its normal content of the various neutral amino acids. At the same time a profound aminoaciduria was produced, including the cationic as well as the neutral amino acids. Indeed, the early effect on lysine excretion was exceptionally strong, although that on cystine later became even stronger. The $N$-methyl derivative of $\alpha$-aminoisobutyric acid produced an aminoaciduria limited to proline and hydroxyproline, but the action on the retention of neutral amino acids by the liver was still general. Two other analogs, $\alpha, \alpha$-diethylglycine and $\alpha, \alpha$-dicyclopropylglycine, structurally designed to minimize their reactivity with known transport systems, showed weak and negligible effects, respectively, on both the hepatic retention and the renal excretion of amino acids. These associations, together with the metabolic inertness of the test substances, indicate that the above effects arise from competition for transport. Inclusion of $\alpha$-aminoisobutyric acid in the diets of young rats inhibited their growth in approximate correspondence to the decrease in food intake.

\section{INTRODUCTION}

One of the significant steps in the metabolism of the amino acids lies between the plasma amino acids and the tissue amino acids. This step is the uphill transport step, first detected over a half-century ago ${ }^{3}$. Its existence, as we have emphasized elsewhere ${ }^{4-6}$ greatly influences the interpretation one places on changes in the concentrations of the amino acids in plasma. This transport step is readily subject to inhibition by elevating the concentration of any single amino acid reactive with it, a circumstance that arises from the limited specificity characteristically shown by the principal amino acid transport systems. An interesting case which we predicted in I953 (ref. 7) is the action of the high phenylalanine levels characteristic of phenylketonuria. Such elevations of phenylalanine have recently been shown to decrease the levels of leucine, isoleucine, valine and methionine otherwise maintained in the brain ${ }^{8,9}$.

Abbreviations: AIB, $\alpha$-aminoisobutyric acid; DEG, $\alpha, \alpha$-diethylglycine; DCG, $\alpha, \alpha$-dicyclopropylglycine; MeAIB, $N$-methyl derivative of AIB.

* Portions of the present results have been reported in preliminary form ${ }^{1,2}$. 
Several years ago one of us proposed that the transport step might plausibly be a site at which the deleterious effects of dietary excesses of one or several amino acids might be produced ${ }^{4,5}$. In that study we found that feeding almost any amino acid in amounts sufficient to overwhelm the capacity for its catabolism sharply lowered the ability of the liver to retain a test amino acid, which in the specific instance was glycine. Amino acids metabolized so rapidly that they failed to accumulate did not have this effect ${ }^{4}$.

The difficulty in being sure that the effect of supplying an amino acid in excess occurs at the transport step is that at the same time the metabolic reactions concerned with the utilization of that amino acid will undoubtedly be accelerated, and one or more intermediate metabolites may accumulate. In addition some co-reactants in the same metabolic sequence might be depleted. Either of these factors, rather than the presence of the amino acid per se, could produce an observed growth inhibition. To minimize this problem we have administered to rats several difficultly metabolized "model" amino acids. These enter to no more than a minuscule extent into any degradative or synthetic reaction, a circumstance that should simplify the interpretation of their action on amino acid distribution. This communication reports findings on administering three amino acids of the general structure $\mathrm{R}_{2} \mathrm{C}\left(\mathrm{NH}_{3}{ }^{+}\right) \mathrm{COO}^{-}$, namely $\alpha$-aminoisobutyric acid (AIB), $\alpha, \alpha$-diethylglycine (DEG) and $\alpha, \alpha$-dicyclopropylglycine (DCG). The first of these undergoes transport by one or more systems shared with ordinary amino acids (see, for example, ref. Io). In agreement, it produces a severe disturbance in the distribution of these ordinary amino acids. The second has poor reactivity with the usual systems for amino acid transport ${ }^{10,11}$, the third very little if any (D. D. Jones And H. N. Christensen, unpublished results). In agreement DEG produces a small effect on amino acid distribution, and DCG almost none at all. In addition, the $N$-methyl derivative of AIB (MeAIB) has been observed to increase the urinary excretion of proline and hydroxyproline and to decrease the relative hepatic concentrations of these and several other amino acids.

\section{METHODS}

$\mathrm{AIB}, \mathrm{MeAIB}$ and DEG were synthesized in this laboratory using either $\mathrm{K}^{12} \mathrm{CN}$ or $\mathrm{K}^{14} \mathrm{CN}$ (refs. I2-I5). DCG was synthesized by the Ash Stevens Company, Detroit. These amino acids were administered in isoosmotic solution either intraperitoneally or intrajugulary (single injection or by continuous infusion) to male Sprague-Dawley rats weighing $250-400 \mathrm{~g}$. For $18-20 \mathrm{~h}$ prior to an experiment, food had been withheld.

Immediately after the intraperitoneal injection, the animal was placed in a cage over a funnel for the collection of urine. At the end of the timed interval, a whiff of ether was given to encourage the voiding of the last of the bladder contents. Blood was taken from the renal vein under ether anesthesia, and the liver removed, producing death. The musculature of the right thigh was also excised, and these 2 tissues were placed on ice. Blood plasma was collected and deproteinized with an equal volume of $10 \%$ sulfosalicylic acid. Approx. I g of each tissue was weighed immediately into tared test tubes. A rotating glass pestle was used to homogenize the tissues with I $\mathrm{ml}$ of $0.2 \mathrm{M} \mathrm{NaCl}$. The homogenate was diluted with sulfosalicylic acid solution to a volume that was ro times the fresh weight of the tissue and which produced a final concentration of $3 \%$ sulfosalicylic acid ${ }^{\mathbf{1 6}}$. The homogenate was heated in a 
boiling-water bath for $5 \mathrm{~min}$, the coagulum was centrifuged down, and the supernatant solution removed and stored at $-20^{\circ}$.

Two of the test amino acids, AIB and DCG, could be measured satisfactorily on the ion-exchange chromatograms of the tissue extracts. For DCG that measurement served for our analyses. The color intensity obtained for AIB with ninhydrin was I0.4\% of that for leucine; for DCG, $4.5 \%$ of that for leucine. Elution of DCG occurred as a symmetrical peak, just before that for methionine. For the measurement of AIB we confirmed that chromatography and liquid scintillation counting gave the same analytical results (Table I), as predicted from earlier observations that it is not metabolized. MeAIB emerged near glutamic acid as a clear-cut peak on the chromatogram, when ${ }^{14} \mathrm{C}$ counting was used for detection, although it gave no color with ninhydrin. The large quantity of it present in the urine samples interfered somewhat with the measurement of aspartate, threonine, serine and asparagine plus glutamine. DEG gave a clear-cut peak near valine on the chromatogram when detected by ${ }^{14} \mathrm{C}$ counting, but it also gave no color with ninhydrin. The quantity present in urine samples prevented the measurement of alanine, cystine and valine. For extracts of plasma and tissues, however, the amounts of the test substances present were not large enough to disturb the chromatographic analysis of any other amino acid.

\section{TABLE I}

CORRESPONDENCE BETWEEN ANALYSIS BY CHROMATOGRAPHY AND BY SCINTILLATION COUNTING FOR $\alpha$-AMINOISOBUTYRIC ACID IN THE LIVER

The dose was Io mmoles $/ \mathrm{kg}$ body weight by intraperitoneal injection, and the time before sacrifice, $2 \mathrm{~h}$ in the first 3 experiments. In the fourth, $8.2 \mathrm{mmoles} / \mathrm{kg}$ was administered at a uniform rate by a jugular vein during the $2.5^{\text {-h }}$ period before the analyses.

\begin{tabular}{lll}
\hline Expt. & \multicolumn{2}{l}{ Found (mmoles/kg fresh tissue) } \\
\cline { 2 - 3 } & $\begin{array}{l}\text { Scintillation } \\
\text { counting }\end{array}$ & Chromatography \\
& & \\
\hline & & 36.1 \\
I & 34.9 & 40.6 \\
2 & 39.7 & 34.7 \\
3 & 31.0 & 31.1 \\
\hline
\end{tabular}

\section{Studies on adrenalectomized animals}

Bilateral adrenalectomy was performed on rats anesthetized with ether. Postoperatively, the animals were maintained on the usual rat chow diet and provided with water containing $\mathrm{I} \% \mathrm{NaCl}$ for $7-\mathrm{I} 4$ days before the experiments. The absence of traces of adrenal tissue was considered to be confirmed by the finding of a $10-20 \%$ decrease in the level of the blood sugar of the operated animals after a 24 -h fast, compared with intact fasting animals.

\section{Methods of scintillation counting and amino acid analysis}

Disintegrations in the urine, and in the deproteinized extracts of plasma, liver and muscle were counted for $5^{-}$or Io-min intervals using a Packard Tri-Carb scintillation spectrometer. The scintillator was a toluene-ethanol solution of 2,5-diphenyloxazole and $p$-bis $[2,4$-(methyl-5-phenyloxazolyl) $]$ benzene. Amino acid measure- 
ments were made chromatographically with an automatic Phoenix amino acid analyzer, the acidic and neutral amino acids on a $150-\mathrm{cm}$ column ${ }^{17}$ and the basic amino acids, except for arginine, on a $60-\mathrm{cm}$ column of Spherix resin $\mathrm{xx} 8-60-\mathrm{I}$. The latter column was adapted by us for the elution of basic amino acids with $0.38 \mathrm{M}$ sodium citrate buffer $\left(\mathrm{pH}_{5} .28\right)$ at a flow rate of $80 \mathrm{ml} / \mathrm{h}$. After $\mathrm{I} 60 \mathrm{ml}$ of buffer had passed through the column, ninhydrin solution was admitted to the reaction coil, and the peaks for ornithine, lysine and histidine were observed at I94, 222 and $454 \mathrm{ml}$ of eluting buffer, respectively. The levels of arginine in the samples were measured on a $10 \mathrm{~cm} \times 0.6 \mathrm{~cm}$ column of Spherix $\times x 8$-Io, according to the instructions provided by the Phoenix Precision Instrument Company. A Nuclear-Chicago scintillation-flow counter model $635^{\circ}$ was connected with the amino acid analyzer to measure amino acids that gave little or no color with ninhydrin. For calculation of apparent concentrations in the cell water, the liver was taken to contain $49 \%$ intracellular and $22.5 \%$ extracellular water.

\section{RESULTS}

\section{Distribution and excretion of the injected amino acid}

Table II extends into higher dose ranges our previous results on the tissue uptake and urinary excretion of $\mathrm{AIB}^{\mathbf{1 8}, 19}$. Approximately the first half of a dosage of Io mmoles/kg body weight injected intraperitoneally had been excreted into the urine after $4-6 \mathrm{~h}$. The plasma and liver levels had passed their peaks at this point, but the muscle level may not have. At lower dosages the excretion rate is of course much slower, and one can produce a comparatively stable level of AIB in the animal for many hours ${ }^{19}$.

When the same quantity of $\mathrm{AIB}$ was injected subcutaneously as a $0.3 \mathrm{M}$ solution,

TABLE II

DISTRIBUTION AND EXCRETION OF AIB UNDER VARIOUS EXPERIMENTAL CONDITIONS See text for details.

\begin{tabular}{|c|c|c|c|c|}
\hline \multirow{2}{*}{$\begin{array}{l}\text { Dose } \\
(\text { mmoles } / \mathrm{hg})\end{array}$} & \multirow{2}{*}{$\begin{array}{l}\text { Time from start } \\
\text { of injection } \\
(h)\end{array}$} & $A I B$ con & & \multirow{2}{*}{$\begin{array}{l}\text { Urinary } \\
\text { excretion } \\
(\% \text { of dose) }\end{array}$} \\
\hline & & $\begin{array}{l}\text { Plasma } \\
(m M)\end{array}$ & $\begin{array}{l}\text { Liver Muscle } \\
\text { (mmoles/kg cell water) }\end{array}$ & \\
\hline
\end{tabular}

\section{Intraperitoneal injection}

\begin{tabular}{|c|c|c|c|c|c|}
\hline I & 2.0 & I. I & 6.1 & O. I I & O.I I \\
\hline \multirow[t]{3}{*}{ IO } & 2.0 & 13.5 & 66 & 0.5 & 10.9 \\
\hline & & I 3.8 & $7^{\circ}$ & I. 8 & I I.9 \\
\hline & & $15 . \mathrm{I}$ & 44 & 2.9 & I 3.3 \\
\hline \multirow[t]{2}{*}{ IO } & 4.5 & 3.5 & 43 & $7 \cdot 4$ & $5^{\circ}$ \\
\hline & & 5.0 & & & 55 \\
\hline \multirow[t]{2}{*}{ IO } & 6.0 & & & & 49 \\
\hline & & & & & $6_{5}$ \\
\hline IO & 24 & 2.5 & & & $\begin{array}{l}87 \\
08\end{array}$ \\
\hline
\end{tabular}

Subcutaneous injection at right scapula

$\begin{array}{lllllll}\text { IO } & 2 & 0.9 & 5.6 & 0.28 & 0.12\end{array}$


its appearance in the plasma was far slower, and only I \% as much was excreted in the first $2 \mathrm{~h}$ (Table II). These results reveal a sluggish movement from the subcutaneous site, which served to explain the absence of any prompt effect on the distribution of ordinary amino acids.

The urinary excretion of MeAIB at low dosages, like that of AIB, is very slow. Fig. I shows the loss at a rate of about Io $\%$ in $24 \mathrm{~h}$ at a dosage of $10^{-5}$ mole $/ \mathrm{kg}$ body weight. DEG, in contrast is lost into the urine very much more rapidly at the same low dosage (Fig. I), about $80 \%$ being lost during the 3 rd and 4 th $\mathrm{h}$ after the intraperitoneal injection. This result led us to expect that the amino acid might indeed serve as a suitable control substance for the present research. When we nevertheless found that it causes losses of amino acids from the liver (see below) we turned to DCG, for which we have been unable to detect mediated uptake by the Ehrlich cell (D. D. Jones AND H. N. Christexsen, unpublished results). In this case, $45 \%$ and $53 \%$ of the DCG dose of Io mmoles $/ \mathrm{kg}$ body weight was lost into the urine in $2 \mathrm{~h}$ (Table III). This result may be compared with losses of $20 \%$ for DEG, $3 \mathrm{I} \%$ for MeAIB

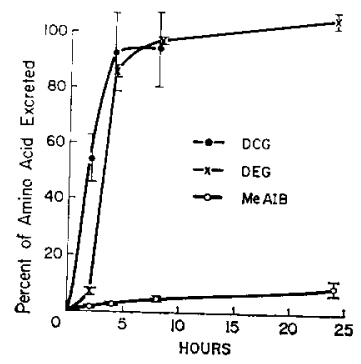

Fig. I. Contrast in rates of urinary excretion of DEG and DCG with that for MeAIB in the rat. Io $\mu$ moles of amino acid in $0.15 \mathrm{M} \mathrm{NaCl}$ solution were injected intraperitoneally into $300-g$ rats. For labeled DEG and MeAIB, the appearance of radioactivity in the urine was followed. DCG was determined by ion-exchange chromatography in the course of the usual analysis for ordinary amino acids. The vertical lines drawn through the points represent the range of values found about the mean for 2 animals.

TABLE III

Uptake of MeAIB, DEG AND DCG By liver AND MUSCle, and THEIr URINARY EXCRETION FOLLOWING INTRAPERITONEAL INJECTION

Dose, ro mmoles $/ \mathrm{kg}$ body weight. See text for details.

\begin{tabular}{|c|c|c|c|c|}
\hline $\begin{array}{l}\text { Amino acid } \\
\text { injected }\end{array}$ & $\begin{array}{l}\text { Time after } \\
\text { administration } \\
(h)\end{array}$ & $\begin{array}{l}\text { Plasma } \\
(m M)\end{array}$ & $\begin{array}{l}\text { Liver Muscle } \\
\text { (mmoles/kg cell water) }\end{array}$ & $\begin{array}{l}\text { Urinary } \\
\text { excretion } \\
(\% \text { of dose })\end{array}$ \\
\hline \multirow[t]{3}{*}{ MeAIB } & 2.0 & го. 6 & 9.8 & $4 \mathrm{I}$ \\
\hline & 2.0 & 7.6 & I. I & I 7.4 \\
\hline & 2,0 & 8.0 & 8.3 & 34 \\
\hline MeAIB & $4 \cdot 5$ & 3.2 & 24.8 & 64 \\
\hline \multirow[t]{2}{*}{ DEG } & 2.0 & 9.4 & 8.3 & 20.3 \\
\hline & 2.0 & 8.2 & I 5.8 & \\
\hline \multirow[t]{2}{*}{ DCG } & 2.0 & 6.7 & I 3.4 & 45 \\
\hline & 2.0 & 6.9 & I 6.9 & 53 \\
\hline
\end{tabular}


(Table III) and II \% for AIB (Table II). The amounts of the three substances still retained in the animal after $2 \mathrm{~h}$ were therefore not enormously different. Comparison of the plasma levels of the 4 test amino acids at $2 \mathrm{~h}(\mathrm{I} 4,7,8$ and $8 \mathrm{mM}$, in the order AIB, DCG, DEG and MeAIB) shows that the tissues were for the first few hours exposed to rather similar external levels of these substances, even though the rates of excretion for the four compounds differ intensely at low dosages (Fig. I). This result arises not only from our having overwhelmed the renal resorptive capacities for all four by the large dosages used, but also from the circumstance that the amino acids resorbed most poorly from the renal tubule and hence excreted the fastest, are at the same time those most nearly restricted to the extracellular compartment of the body.

\section{Effects on urinary excretion of ordinary amino acids}

Fig. 2, upper portion, presents typical observations of the effects of injecting ro mmoles of AIB intraperitoneally. These results show that the rise in urinary amino nitrogen observed by LANG AND OSTER ${ }^{20}$ after AIB administration was due to

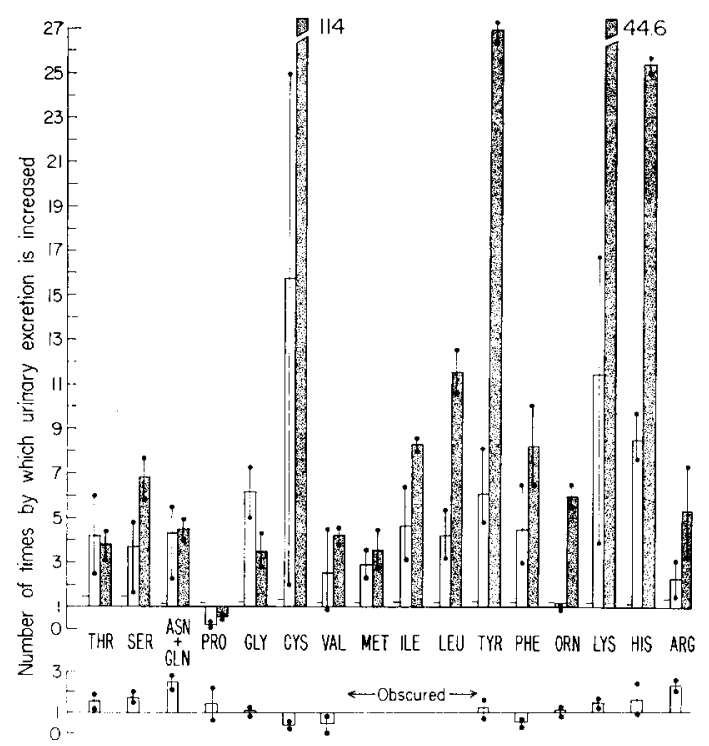

Fig. 2. Effects of AIB and DCG injected intraperitoneally (Io mmoles/kg body weight) on the urinary excretion of amino acids. The height of a bar shows the number of times an animo acid is increased above the average control level. The average control excretion rates were as follows in moles $\times$ IO $^{-9}$ per $\mathrm{kg}$ body weight per h. Asp, 70; Thr, 253; Ser, I 55; Asn + Gln, I8I; Glu, 305; Pro, 86; Gly, I780; Ala, 270; 1/2 Cys, 52; Val, 54; Met, 49; Ile, 27; Leu, 45; Tyr, 20; Phe, 52; Orn, 59; Lys, I 59; His, 49; Arg, 84. Upper part, results with AIB administration; lower part, with DCG. A clear bar represents results $2 \mathrm{~h}$ after injection, comparing 4 (AIB) or 2 (DCG) experimental animals with 9 control animals. A shaded bar represents results after $4.5 \mathrm{~h}$, for 2 experimental versus 2 control animals. The vertical lines drawn to connect two dots represent the range about the mean. The control rats received intraperitoneally $0 . \mathrm{I}_{5} \mathrm{M} \mathrm{NaCl}$ corresponding to the volume of solution injected into the experimental animals. No result is shown for alanine because the AIB excess interfered with that analysis. In the case of DCG the results for 3 other amino acids were obscured. The horizontal marks at the left of the clear bars in the upper section indicate the standard deviation in the upward direction among the 9 controls. These same standard deviations may be taken to apply for Figs. 3,4 and 5. Presumably the standard deviations are slightly smaller for the 4.5-h interval in Figs. $3,4,5$ and 6 , and the $24^{\text {-h }}$ interval in Fig. 3 , because of greater precision in collecting the urine represented by the longer time intervals. 
a general aminoaciduria. All the endogenously present amino acids listed except proline showed increased excretion rates, many of them by factors of 5 or ro or more. The most strongly influenced at $2 \mathrm{~h}$ was lysine; the most strongly affected at $4.5 \mathrm{~h}$ were cystine and lysine. The cystine peak on the chromatograms was identified by comparison with authentic cystine. This identification was reinforced by the large content of sulfhydryl in the urine shown by the nitroprusside test ${ }^{21}$. The plasma level of cystine was less than doubled, whereas the urinary excretion rate was increased by as much as roo times. Similar effects on urinary amino acids were obtained when AIB was fed or infused into a jugular vein. Even the excretion of taurine (not shown) was doubled or tripled.

After $24 \mathrm{~h}$ the excretion of proline was also elevated (clear bars of Fig. 3). The aminoaciduria had largely subsided by the 3 rd day (shaded bars of Fig. 3). Note that we should not yet expect a complete return to a normal urinary composition, because the animal still contained enough AIB to sustain a 24 -h excretion rate of $6 \%$ of the dose; furthermore the excretion of the remaining AIB may be expected to continue for many days, because the AIB load is no longer as overwhelming to its own renal resorption or to that of other amino acids. Therefore the results of Fig. 3 support the interpretation that the action of AIB is a reversible one, due as in other tissues to competition for transport, rather than a lasting intoxication of renal amino acid transport of the kind produced by $\mathrm{D}$-serine ${ }^{2 \mathbf{2}}$. In general the list of amino acids excreted in supernormal amounts on the third day (e.g. glycine, proline, methionine and valine) included the ones whose uptake by the Ehrlich cell is inhibited by AIB, and excluded others (arginine, ornithine, lysine and cystine) whose excretion we had

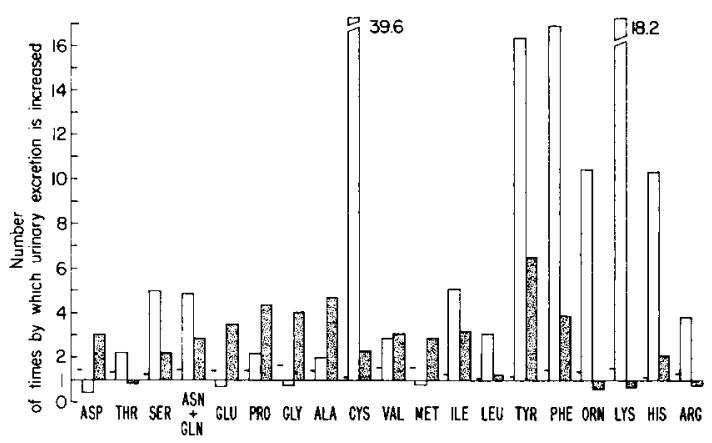

Fig. 3. Subsidence of aminoaciduria after injection of AIB. Same conditions and mode of representation as in Fig. 2, except that a clear bar indicates the rate of excretion of an amino acid by a rat weighing $3 \mathrm{I} 8 \mathrm{~g}$ during the first $24 \mathrm{~h}$ after injection of $\mathrm{AIB}$, relative to the mean 24 -h excretion by two control rats weighing 333 and $43^{\circ} \mathrm{g}$, respectively, and the shaded bar, the excretion during the 3 rd day after the injection. Of the injected dose of AIB, $68 \%$ was excreted in the urine in the first and $6 \%$ in the third 24 -h interval. The marks on the left of the clear bars mark the higher of the 2 control excretion rates.

not expected a priori to find increased by the presence of AIB. Hence we suppose that an improved selectivity of action, more informative as to the separate transport systems that may participate, can probably be obtained by making sequential observations during the period of depletion of the level of the test amino acid in the animal.

In another attempt to secure higher selectivity in the action on renal excretion, 
as well as on the hepatic amino acid levels, to be discussed below, we turned our attention to MeAIB, taking advantage of the finding that amino acids are excluded from several transport systems by their N-methylation ${ }^{23,24}$. Fig. 4 shows (on the same scale as Figs. 2 and 3 ) the effect on the urinary amino acids of injecting intraperitoneally MeAIB, Io mmoles $/ \mathrm{kg}$ body weight. The only two amino acids that showed appreciably increased excretion were proline, by about I3-fold, and hydroxyproline, ordinarily not detectable in the urine of the rat but now at about $\mathrm{I}_{4}$ times the minimal detectable level.
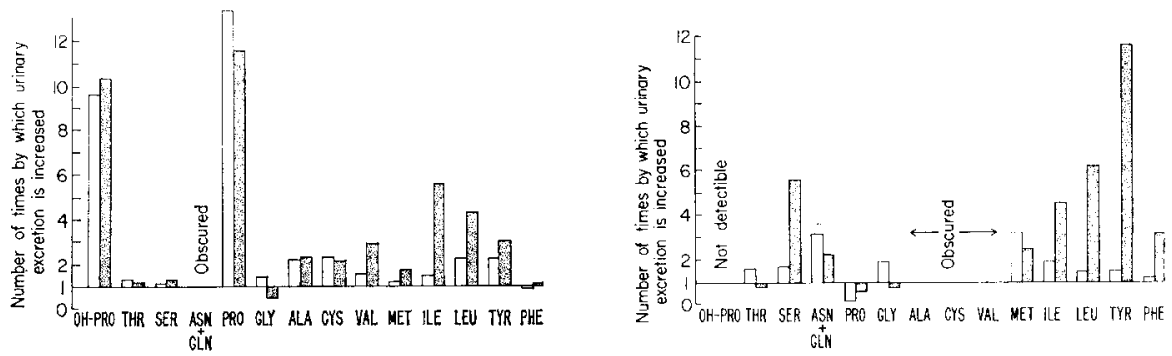

Fig. 4. Effect of intraperitoneal injection of MeAIB ( 1 o mmoles/kg body weight) on the urinary excretion of amino acids. Same mode of representation as in Fig. 2, with two experimental animals studied for $2 \mathrm{~h}$ and one for $4.5 \mathrm{~h}$ being compared with the same control animals represented in that figure. Since hydroxyproline is not present in the normal urine in sufficient concentrations to be detected by the chromatographic procedure used here, the coefficient of increase was calculated on the assumption that the control rate of excretion was $0.01 \mu \mathrm{mole} / \mathrm{kg}$ body weight, the lowest level that can be detected. Hence the approx. ro-fold estimated increases shown are minimal values.

Fig. 5. Effect of intraperitoneal injection of $\mathrm{DEG}$, Io mmoles $/ \mathrm{kg}$ body weight, on the urinary excretion of amino acids. Same conditions as for Fig. 4.

As our first attempt at identifying a "control" substance, i.e., one with no effect on amino acid transport, we injected $\alpha, \alpha$-diethylglycine. This substance at similar levels had a small, although definite, inhibitory action on the principal transport systems of the Ehrlich cell ${ }^{10,11}$. Fig. 5 shows that only rather limited urinary changes were produced during the several hours after its injection. Because the part of the chromatogram where cystine should appear was obscured by the presence of excess DEG, we made separate tests for cystine by the nitroprusside method, and found no more than the usual weak reactivity. This result contrasts sharply with the powerful nitroprusside reaction obtained after AIB administration. Because DEG did show definite though weak effects on amino acid excretion (Fig. 5), as well as on the hepatic levels of amino acids (to be discussed below) we turned to another model amino acid with even lower transport reactivity, DCG. Fig. 2 (lower section) shows that the effects, if any, on the urinary excretion of amino acids were very small.

\section{Action on the distribution of amino acids between plasma and liver}

Two modes of representation of the changes in hepatic amino acids seemed desirable to us: the change in the hepatic level per se of the amino acid, and the change of the partition coefficient of the amino acid between the liver and the plasma. The total content of a free amino acid in the body may in some cases vary widely from animal to animal, as is true for glycine in the guinea pig ${ }^{4}$, so that reference of the level in a tissue to the level in the extracellular fluid becomes necessary to detect effects on 
transport. Fig. 6 and the succeeding figures therefore present both actual hepatic concentration of each amino acid and its concentration relative to the plasma level of the same amino acid. Fig. 6 summarizes the action of AIB, on the distribution of the ordinary amino acids. Every one of the I 2 neutral amino acids listed, with the possible exception of proline, is seen to be decreased on either basis by the administration of AIB. The level of ornithine was also depressed. A single test showed that a dose of I mmole $/ \mathrm{kg}$ body weight also sufficed to lower the relative hepatic concentrations of the same II neutral amino acids, by a mean of $22 \%$, S.D. $=7 \%$. Although this single
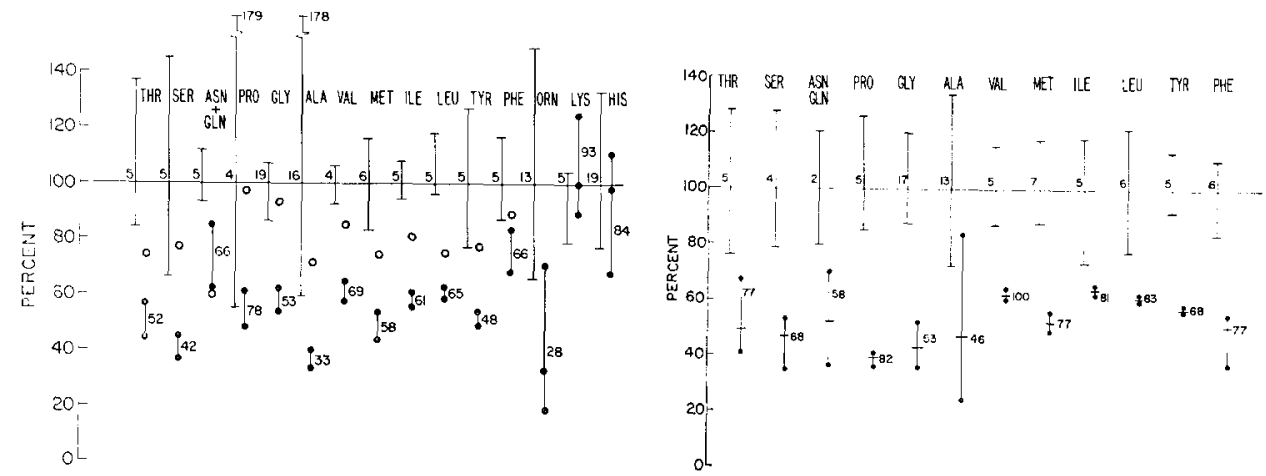

Fig. 6. Effect of intraperitoneal injection of AIB on the distribution of amino acids between the liver and the plasma. The first amino acid listed, threonime, will be used to explain the mode of presentation. In 4 control rats injected with $\mathrm{NaCl}$ solutions, the level of threonine calculated for the level cell water averaged 5 times that of the plasma. This value has been set at roo \%, the value 5 having been inscribed at that point, and a vertical line drawn to show the range of the partition coefficients in the 4 control rats. Directly below the abbreviation Thr another vertical line joining two filled circles indicates that 2 experimental animals, receiving Io mmoles AIB per $\mathrm{kg}$ body weight showed only 45 and $58 \%$ of the mean control partition coefficient (reading from the scale at the left). The value of 52 inscribed beside this line indicates that their hepatic concentration of threonine was lowered as an average to $52 \%$ of the mean control value. The open circle shows that a rat receiving only $\mathrm{I}$ mmole of AIB per $\mathrm{kg}$ body weight had the partition coefficient, liver to plasma, lowered to $74 \%$. The mean control concentration of threonine in the liver, in mmoles/lkg cell water, can be obtained by multiplying its mean plasma concentration (0.19 $\mathrm{mM}$ ) by the value inscribed on the line for roo \%, namely 5 . The range can be obtained by multiplying the resulting product by 0.84 and $\mathbf{1} .37$. Multiplying instead by 0.45 and $0.5^{8}$ yields the levels of hepatic threonine for the experimental animals. The mean control plasma concentrations of the several amino acids were as follows: Asp, o.oI2; Thr, o.I9; Ser, 0.28; Asn + Gln, o.4I; Glu, o.I7; Pro, o.I3; Gly, o.40; Ala, o.40; I/2 Cys, o.082; Val, o.I9; Met, 0.049; Ile, o.Ior; Leu, o.I6; Tyr, 0.067; Phe, 0.072 ; Orn, 0.056 ; Lys, 0.37 ; His, 0.077 . The plasma concentrations of AIB in 3 experimental animals $2 \mathrm{~h}$ after the injection of ro mmoles $/ \mathrm{kg}$ body weight were I 3.5 , I3.8 and I 5 . I $\mathrm{mM}$, and I.I $\mathrm{mM}$ for the rat receiving only I mmole of AIB. For the liver cell water, AIB reached calculated levels of $66.0,70.3$ and $40.3 \mathrm{mM}$ for the larger dose, and 6. $1 \mathrm{mM}$ for the smaller dose.

Fig. 7. Effect of intraperitoneal injection of AIB on the distribution of amino acids between the liver and the plasma in adrenalectomized rats. Dosage again ro mmoles/kg body weight. Same mode of representation as in Fig. 6. The 3 experimental animals showed plasma levels of 12,22 and I $7 \mathrm{mM}$ AIB, hepatic levels of $6 \mathrm{I}, 7 \mathrm{I}$, and $45 \mathrm{mmoles} / \mathrm{kg}$ cell water. The control values represent 4 adrenalectomized animals.

experiment did not by itself establish an effect on any given amino acid, it gave us no encouragement that a more selective action can be obtained for AIB at this dosage. Fig. 7 shows that highly similar effects of AIB on the distribution of amino acids between liver and plasma were observed for adrenalectomized animals. Again the effects of AIB apply to every neutral amino acid tested. 
MeAIB also lowered the hepatic levels of neutral amino acids, the effect being definite for 5 of the neutral amino acids for each of which 3 observations are available (Fig. 8). No tendency was noted for either the amino acids with short or polar side chains, or those with large apolar side chains, to escape the effect. The depressing effect of MeAIB on the hepatic retention of threonine, serine, proline, glycine and methionine was also observed in one rat $4.5 \mathrm{~h}$ after the dose, and in an animal receiving I4. 6 mmoles $/ \mathrm{kg}$ of MeAIB by continuous intrajugular infusion during $2.5 \mathrm{~h}$ under Surital anesthesia.

In the tests of DEG, only in the cases of alanine and tyrosine are the decreases in the relative or absolute hepatic levels anywhere nearly as large as those produced by AIB (Fig. 9). Nevertheless a widespread tendency for the relative hepatic levels of the neutral amino acids to be somewhat lowered may be noted. Only serine and
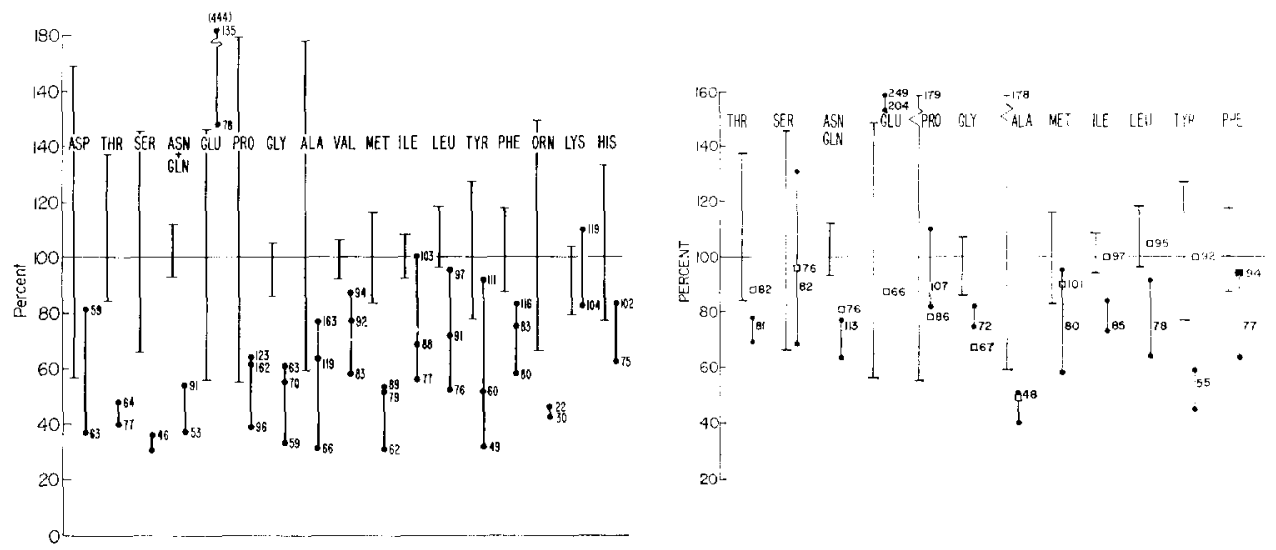

Fig. 8. Effect of injection of MeAIB on the distribution of amino acids between the liver and the plasma in the rat. Dosage ro mmoles $/ \mathrm{kg}$ body weight. Same mode of representation, same control animals, as in Fig. 6. The 3 experimental animals indicated by showed $8,7.6$ and $10.6 \mathrm{mM}$ MeAIB in the plasma, and 33, 63 and 42 mmoles MeAIB per kg cell water in the liver at $2 \mathrm{~h}$ after the injection. The value in parentheses for glutamic acid shows where the uppermost value would appear if the scale were extended.

Fig. 9. Effect of intraperitoneal injection of DEG ( 10 mmoles per $\mathrm{kg}$ ) on the distribution of amino acids between the liver and the plasma. Same mode of representation, same control observations as in Fig. 6. The 2 experimental animals showed plasma levels of 8 and $9 \mathrm{mM}$ DEG and hepatic levels of $\mathrm{I} 6$ and 8 mmoles DEG per $\mathrm{kg}$ cell water at $2 \mathrm{~h}$ after the injection. The squares represent results obtained in a adrenalectomized rat $2 \mathrm{~h}$ after the same dose compared with controls of Fig. 7 . The plasma DEG level was 9.4, 8.2 $\mathrm{mM}$ (adrenalectomized:7.4 mM) and the hepatic levcl $8.3,15.8$ mmoles $/ \mathrm{kg}$ cell water (adrenalectomized: 9.7 mmoles).

proline showed any probability of escaping the effect. DCG in contrast did not significantly lower the relative hepatic level of any neutral amino acid (Fig. Io). Only in the case of proline was there a distinct effect on the absolute level in the liver, but because the plasma proline was elevated in the same proportion the action cannot be identified as one on transport. Nevertheless dicyclopropylglycine itself was concentrated nearly 2-fold by the liver (Table III), by a process subject to inhibition by diethylglycine and other amino acids (Table IV). This strange behavior recalls the equally odd observation that diethylglycine is concentrated by the Ehrlich cell by a process not serving measurably for dicyclopropylglycine or ordinary amino acids ${ }^{11}$. 
TABLE IV

EFECTS OF INJECTING OTHER AMINO ACIDS (IO mmoles/kg BODY WEIGHT, INTRAPERITONEALLY) ON UPTAKE OF DCG (O.I mmole/kg) BY LIVER OF INTACT RAT

\begin{tabular}{lll} 
Inhibitory & Number & {$[D C G]_{\text {liver }}[D C G]_{\text {plasma }}$} \\
amino & of & $\pm S . D$. \\
acid & observations & \\
\hline
\end{tabular}

$\begin{array}{llll}\text { None } & 6 & \text { I.92 } & =0.2 \mathrm{I} \\ \text { AIB } & 3 & \text { I.6I } & \pm 0.19 \\ \text { DEG } & 3 & \text { I.I3 } & : \pm 0.70 \\ \text { Methionine } & 2 & \text { I.44 } & \end{array}$
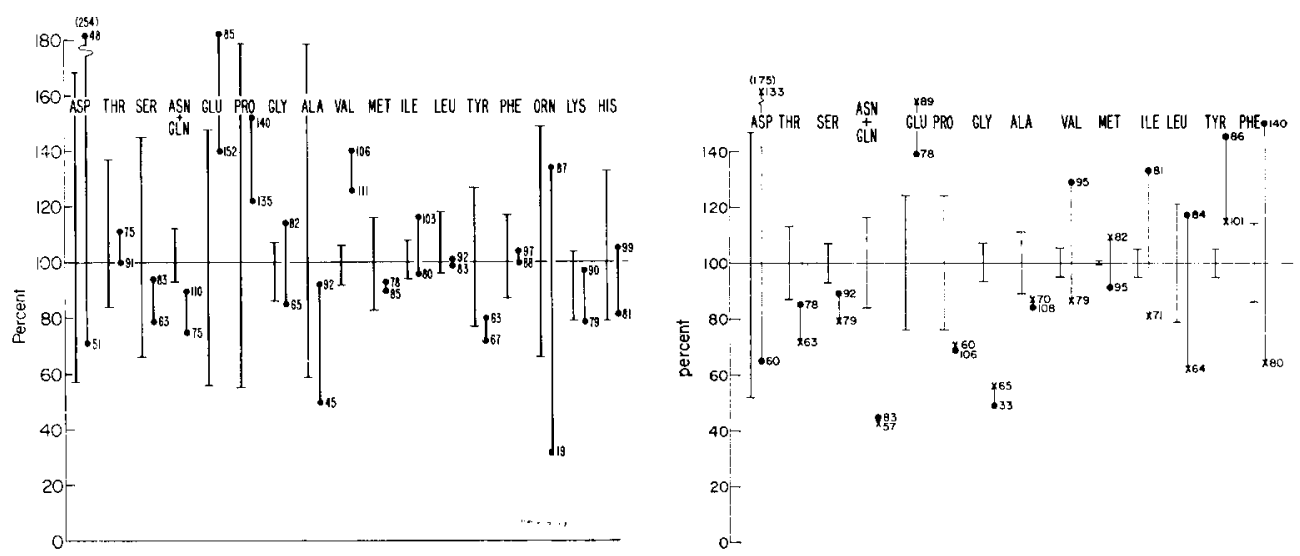

Fig. Io. Effect of intraperitoneal injection of DCG, ro mmoles/kg body weight, on the distribution of amino acids between the liver and the plasma. Same mode of representation and same control observations as in Fig. 6. The 2 experimental animals showed plasma levels of 6.7 and $6.9 \mathrm{mM}$ DCG, and hepatic levels of $\mathrm{I}_{3.4}$ and $\mathrm{I} 6.9$ mmoles DCG per $\mathrm{kg}$ cell water at $2 \mathrm{~h}$ after injection.

Fig. Ir. Effects on muscle amino acids of feeding AIB to young rats for 3 weeks. In analogy to Fig. 6, the muscle content of each amino acid is shown relative both to its plasma level (scale at left) and relative to its level in the muscle of the control animals (numbers inscribed beside the points). The control animals were pair-fed with the experimental rats. The mark $x$ represents an experimental animal receiving $6 \%$, and the filled circle, one receiving $10 \%$ AIB in the diet, consumed ad libitum. These animals were selected at random from those presented in Tables $\mathrm{V}$ and VI.

\section{Action on muscle amino acid levels}

At the plasma concentrations of $\mathrm{r}_{3.5}, \mathrm{I3} .8$, and $\mathrm{I5}$.I mM, obtained $2 \mathrm{~h}$ after intraperitoneal injection of Io mmoles of AIB per kg body weight, the muscle samples contained only 0.5, I. 8 and $2.9 \mathrm{mmoles} / \mathrm{kg}$ cell water, respectively. The only indication of a change in the muscle levels of the endogenously present amino acids was an increase in the aggregate levels of asparagine and glutamine and in the level of glutamic acid. These changes are of unknown significance. Similarly, after DCG injection, when the plasma levels were 6.7 and $6.9 \mathrm{mM} \mathrm{DCG}$ the content in muscle was only $\mathrm{r} .6$ and $2.2 \mathrm{mmoles} / \mathrm{kg}$ cell water. Again no indication was seen of a lowering of the level of any amino acid in muscle, relative to the plasma level. Likewise, no muscle changes were found after injection of DEG or MeAIB. In view of the sluggish 
entry of the test amino acids into muscle, the 2 -h period of exposure appears to have been too short to be informative. The animals maintained on 6 and I0\% AIB for 3 weeks did show distinctly lowered muscle levels of glycine, alanine, serine, threonine, proline and asparagine plus glutamine (Fig. II). These are amino acids whose transport is strongly inhibited by AIB in the Ehrlich cell ${ }^{10}$. In the case of the brain under the same conditions the decreases in threonine and asparagine phis glutamine were the only distinct changes.

\section{Feeding experiments}

Table $V$ compares the weight gains of weanling rats fed diets containing protein at various levels, to which 3-I0\% AIB had been added. An aminoaciduria resembling that of the AIB-injected animals occurred at the 3 levels of dietary AIB tested. At a $27 \%$ level of protein, $3 \%$ AIB caused only a mild reduction of food intake, the weight gains being insignificantly different from those of pair-fed controls. At 8 or $12 \%$ protein in the diet, the decrease in growth produced by the presence of $3 \% \mathrm{AIB}$ was much more severe, but still no greater than that accounted for by the decrease

\section{TABLE V}

Growth of Weanling rats on diets containing AIB or MeAIB, Relative to pair-Fed CONTROLS

Note that for the group receiving $6 \% \mathrm{AIB}$ and $27 \%$ casein, the same final weight was attained by the controls, even though the controls had averaged 1o\% lighter at the beginning of the experiment.

\begin{tabular}{|c|c|c|c|c|c|c|}
\hline \multirow[t]{2}{*}{ Diet } & \multirow{2}{*}{$\begin{array}{l}\text { Number of } \\
\text { animals }\end{array}$} & \multicolumn{4}{|c|}{ Body weight $(g \pm S . D)}$. & \\
\hline & & Beginning & $I$ week & 2 weeks & 3 weeks & \\
\hline \multicolumn{7}{|c|}{$3 \% A I B+27 \%$ casein } \\
\hline $\begin{array}{l}\text { Control } \\
\text { Control + AIB }\end{array}$ & $\begin{array}{r}9 \\
\text { IO }\end{array}$ & $\begin{array}{l}43 \pm 3.4 \\
43 \pm 3.9 \\
6 \% A I B+\end{array}$ & $\begin{array}{l}76 \pm 4 \cdot 3 \\
75 \pm 6.0 \\
\% \text { casein }\end{array}$ & $\begin{array}{l}\text { I } 20 \pm 4.8 \\
\text { II } \pm \quad 7 . I\end{array}$ & $\begin{array}{l}\text { I53 } 5 \\
\text { I } 40 \pm\end{array}$ & $\begin{array}{l}5 \cdot 5 \\
6.7\end{array}$ \\
\hline $\begin{array}{l}\text { Control } \\
\text { Control + AIB }\end{array}$ & $\begin{array}{l}\text { 10 } \\
\text { Io }\end{array}$ & $\begin{array}{l}35 \pm 3.2 \\
39 \div 5.6 \\
I 0 \% A I B\end{array}$ & $\begin{array}{l}57 \pm 6.9 \\
60 \pm 6.8 \\
7 \% \text { casein }\end{array}$ & $\begin{array}{l}87 \pm \text { II.I } \\
87 \pm 9.5\end{array}$ & $\begin{array}{l}120 \pm I \\
120=1\end{array}$ & $\begin{array}{l}\text { I } 3.7 \\
\text { I I } .5\end{array}$ \\
\hline $\begin{array}{l}\text { Control } \\
\text { Control + AIB }\end{array}$ & $\begin{array}{l}\text { ro } \\
\text { to }\end{array}$ & $\begin{array}{l}45 \pm 9.1 \\
45 \pm 8.0 \\
3 \% A I B+\end{array}$ & $\begin{array}{l}56+8.1 \\
52+8.6 \\
\% \text { casein }\end{array}$ & $\begin{array}{l}95 \pm 7.6 \\
87 \pm 8.6\end{array}$ & $\begin{array}{l}\text { I } 36= \\
\text { I } 21 \pm\end{array}$ & $\begin{array}{l}8.2 \\
9.2\end{array}$ \\
\hline $\begin{array}{l}\text { Control } \\
\text { Control + AIB }\end{array}$ & $\begin{array}{l}\text { ro } \\
\text { Io }\end{array}$ & $\begin{array}{l}39 \pm 2.5 \\
39 \pm 2.9 \\
3 \% A I B+\end{array}$ & $\begin{array}{l}53 \pm 3.3 \\
55 \pm 3.8 \\
\text { casein }\end{array}$ & $\begin{array}{l}74 \pm 8.9 \\
75 \pm 10.2\end{array}$ & $\begin{array}{l}97 \pm 1 \\
98 \pm 1\end{array}$ & $\begin{array}{l}\text { I5. I } \\
\text { I6.0 }\end{array}$ \\
\hline $\begin{array}{l}\text { Control } \\
\text { Control + AIB }\end{array}$ & $\begin{array}{l}\text { ro } \\
\text { ro }\end{array}$ & $\begin{array}{l}35+3.0 \\
35 \pm 3 \cdot \mathrm{I} \\
3 \% \text { MeAII }\end{array}$ & $\begin{array}{l}39 \div 4.0 \\
40 \div 3 \cdot 1 \\
27 \% \text { casein }\end{array}$ & $\begin{array}{l}49 \pm 5.8 \\
46 \pm 4.5 \\
\text { ays only) }\end{array}$ & $\begin{array}{l}54 \doteqdot \\
56 \div\end{array}$ & $\begin{array}{l}6.7 \\
5.8\end{array}$ \\
\hline $\begin{array}{l}\text { Control } \\
\text { Control + MeAlB }\end{array}$ & $\begin{array}{l}4 \\
4\end{array}$ & $\begin{array}{l}35+3 \cdot 5 \\
35+3 \cdot 3\end{array}$ & $\begin{array}{l}62.5 \pm 8.9 \\
59.8 \pm 8.4\end{array}$ & $\longrightarrow$ & - & \\
\hline
\end{tabular}


in food intake. Similar behavior has been observed repeatedly for diets unbalanced as to their content of ordinary amino acids. At Io \% AIB in the diet containing $27 \%$ protein, growth was measurably impaired in relation to pair-fed controls. The hepatic levels of $\mathbf{I} 3$ amino acids, not including the sum of asparagine and glutamine, tended to be lowered relative to the pair-fed controls at all 3 levels of AIB in the diet, the average severity of the diminution increasing with the AIB content of the diet (Table VI). After 8 days on $3 \%$ MeAIB, the levels in liver and brain for alanine, serine, threonine and aspartic acid were distinctly depressed.

\section{TABLE VI}

THE EFFECT OF AIB INTAKE FOR $2 I$ DAYS ON THE RELATIVE LEVELS OF AMINO ACIDS IN LIVER AND PLASMA

The control rats received the standard $27 \%$ casein diet (Nutritional Biochemicals Company), the experimental rats, the same diet with AIB added. The control concentrations are recorded in mmoles of amino acid per $\mathrm{kg}$ of fresh liver or per 1 of plasma.

\begin{tabular}{|c|c|c|c|c|c|c|}
\hline \multirow[t]{3}{*}{ Amino acid } & \multicolumn{3}{|c|}{ Control animals ( 3 rats) } & \multicolumn{3}{|c|}{ Animal receiving $A I B$} \\
\hline & \multicolumn{2}{|c|}{ Average } & \multirow{2}{*}{$\begin{array}{l}\text { Range } \\
\text { liver/plasma ratio } \\
(\% \text { of mean control })\end{array}$} & \multirow{2}{*}{\multicolumn{2}{|c|}{$\begin{array}{l}3 \% \\
\text { liver/plasma ratio } \\
(\% \text { of mean control })\end{array}$}} & \multirow[t]{2}{*}{$I 0 \%$} \\
\hline & Liver & Plasma & & & & \\
\hline Aspartate & 2.68 & 0.02 & $47^{-I} 7^{8}$ & 247 & $\mathbf{I} 37$ & 45 \\
\hline Threonine & 0.98 & 0.27 & $62-126$ & $5^{\circ}$ & 70 & 38 \\
\hline Serine & $1.5^{\circ}$ & 0.33 & $83-$ I I 7 & 56 & $7^{2}$ & 30 \\
\hline Asparagine + glutamine & 0.97 & 0.26 & $49-163$ & $4 I$ & 67 & 37 \\
\hline Glutamate & 2.84 & $0.5^{\circ}$ & $55-\mathrm{I} 65$ & 280 & I 16 & 95 \\
\hline Proline & 0.36 & 0.16 & $40-113$ & 43 & 36 & $2 I$ \\
\hline Glycine & 3.23 & 0.29 & $69-131$ & 74 & $8 \mathrm{I}$ & 90 \\
\hline Alanine & 3.14 & 0.31 & $66-I 39$ & 76 & 45 & 43 \\
\hline Valine & 0.44 & 0.17 & $77-146$ & $9 \mathrm{I}$ & $5^{\circ}$ & 73 \\
\hline Methionine & 0.13 & 0.06 & $8 I-109$ & $6 I$ & 86 & 76 \\
\hline Isoleucine & 0.26 & 0.09 & $67^{-1} 59$ & 66 & 53 & 106 \\
\hline Leucine & $0.5^{2}$ & 0.12 & $7 \mathrm{I}-\mathrm{I} 40$ & 82 & $4^{8}$ & 93 \\
\hline Tyrosine & 0.17 & 0.08 & $68-I_{4} I$ & 108 & 68 & 109 \\
\hline Phenylalanine & 0.20 & 0.05 & $62-140$ & $7^{2}$ & 50 & 67 \\
\hline Ornithine & 0.30 & 0.05 & $39-161$ & $\gamma=$ & 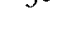 & $19^{*}$ \\
\hline Lysine & 1.05 & 0.67 & $88-112$ & & & $50^{\star}$ \\
\hline Histidine & 0.66 & 0.06 & $96-104$ & & & $57^{\star}$ \\
\hline Arginine & 0.07 & 0.12 & $95-105$ & & & $16{ }^{*}$ \\
\hline
\end{tabular}
32 days.
DIscussIon
The action of high levels of AIB in producing aminoaciduria, as well as its
depressing effect on the retention of amino acids in the liver, proved unexpectedly
comprehensive. Indeed the strongest actions on renal excretion occurred for the
cationic amino acids and cystine, and not for the small neutral amino acids whose
transport is most strongly affected by AIB in many types of isolated cells or tissues.
The transport model I-aminocyclopentanecarboxylic acid", "cycloleucine", has
recently been observed to give related results. We were discouraged from including

* These values were obtained for a different rat than the others, which was fed the diet for 
it in this study because of its special toxicity. When cycloleucine was fed to rats at a level of $0.1 \%$ of the diet, the distribution of amino acids was not modified, relative to pair-fed controls ${ }^{26}$. Subsequent to the preliminary publication of our results $s^{1,2}$, BRown has, however, reported that cancer patients receiving cycloleucine at barely sub-toxic doses excrete increased quantities of cystine, lysine, ornithine and arginine, as well as of taurine, threonine, valine, tyrosine and histidine ${ }^{26}$. WEBBER $^{27}$ observed no increase in the excretion of cystine by dogs infused with AIB, but he informs us that he has now confirmed our observation of the effect in the rat.

In isolated cells $A I B$ and cycloleucine have very weak actions on the uptake of cationic amino acids ${ }^{28}$, and for such cells we have not been able to observe a clearly mediated uptake of cystine. Instead cysteine seems to be the form in which the sulfur amino acid is taken up, by a process which at least in the Ehrlich cell AIB does inhibit ${ }^{23,24}$.

Following the proposal of DENT, SENIOR AND WALSHE ${ }^{29}$, the renal tubular resorption of cystine has been supposed to occur by the same transport system serving for the cationic amino acids. Evidence for this view includes the observation of RoBSON AND ROSE ${ }^{30}$ that in man lysine infusion increases the excretion of cystine, arginine and ornithine. More recently, however, the uptake of cystine into rat kidney slices has been observed not to be inhibited by lysine ${ }^{31}$, and intestinal cystine transport was found present in the absence of lysine transport in one type of cystinuria ${ }^{32}$. These observations indicate that cystine and lysine probably are not uniformly transported by the same agency. The exodus of cysteine from kidney slices has, however, been reported to be inhibited by the cationic amino acids ${ }^{33}$.

If we were to accept the view that AIB and cycloleucine cause cystine excretion by inhibiting the resorption of cysteine, we still would not have clearly accounted for the accompanying appearance of large amounts of lysine and other basic amino acids in the urine. Conceivably these effects arose simply because high enough levels of AIB or cycloleucine were reached to react directly with a transport system for cationic amino acids. Overlaps in reactivity appear to be characteristic for isolated cells ${ }^{10}$. WEBBER $^{34}$ observed that raising the plasma level of any of several neutral amino acids by continuous infusion into the dog increased the clearance of lysine, ornithine, arginine and histidine, although stronger effects were obtained on the various neutral amino acids. MUNCK ${ }^{35}$ has shown that a system transporting cationic amino acids into the small intestine of the rat is sufficiently reactive with leucine so that leucine stimulates countertransport of lysine.

It is possible instead that $A I B$ affected the resorption of lysine, arginine and ornithine indirectly. For example AIB might be expected to inhibit histidine resorption from the renal tubule. Since histidine behaves both as a neutral and a cationic amino acid the resulting high levels of histidine in the lumen could in turn interfere with lysine resorption. Or conceivably the interconversion of cystine and cysteine may transmit inhibitory effects from one transport system to another. Another form of the same hypothesis can be proposed for the liver. Undoubtedly several of the amino acids are concentrated into the cell by a system directly inhibited by AIB. These in turn might normally be exchanged for other amino acids through a second system which is not directly reactive with $\mathrm{AIB}^{10}$. Even during the $2 \mathrm{~h}$ of our shorter experiments, the inhibitory influence of AIB could thus have been transmitted in steps to all the neutral amino acids. Periods of observation much shorter than $2 \mathrm{~h}$ 
may be necessary for the discrimination of separate transport systems for amino acids in the liver.

The action of MeAIB on the urinary loss of amino acids was sharply limited to proline and hydroxyproline, which like it are secondary amino acids. These two appear to share with glycine a transport system of the kidney ${ }^{36}$, and with sarcosine and other $N$-methylglycines, a transport system of the hamster intestine ${ }^{37}$ and one of the Ehrlich cell ${ }^{24}$. Note that glycinuria was not produced by MeAIB in our experiments. The narrow specificity shown by MeAIB in its renal action emphasizes by contrast the unexpectedly wide scope of the action of AIB, both on the liver and the kidneys. Since the scope is very wide at both anatomic points, we have no basis for concluding that the hepatic amino acid transport systems are for some reason inherently unresolvable, even though this investigation has made at best only a modest beginning of such a resolution.

How much metabolic significance should be accorded to a rather generalized lowering of hepatic amino acid levels of the type produced by administering AIB? These levels apparently can be kept somewhat lowered for weeks without an effect on growth much greater than that produced by the coincident reduction in food intake. We cannot exclude the possibility that more severe consequences would appear, were the lowering of the liver amino acids more asymmetrical. Furthermore, the liver appears to occupy a strategic position with regard to maintenance of the plasma levels of most of the amino acids $^{4,38}$ presumably because this organ is a principal site of their net destruction and of their formation and (in the postabsorptive state) of their release from protein. This circumstance may well limit somewhat the risk to hepatic function arising from interference with the uptake of one or several amino acids. A developing tissue that depends for amino acids on sources outside itself, for example the brain, may be expected to be much more vulnerable to an inhibition of its amino acid uptake.

\section{ACKNOWLEDGEMENT}

This work was supported in part by a grant (HD oI 233) from the Institute for Child Health and Human Development, National Institutes of Health, Public Health Service.

\section{REFERENCES}

I A. M. Cullen, J. -P. Antonioli And H. N. Christensen, Federation Proc., 26 (I967) 522.

2 A. M. Cullen and H. N. Christensen, Federation Proc., 25 (I966) $54 \mathrm{I}$.

3 D. D. Van Slyke and G. M. Meyer, J. Biol. Chem., i6 (I9I3-I4) 197.

4 H. N. Christensen, J. A. Streicher and R. Elbinger, J. Biol. Chem., I 72 (I948) 515.

5 H. N. Christensen, Federation Proc., 22 (I I Io) I963.

6 H. N. Christensen, in J. H. Leathem, Protein Nutrition and Free Amino Acid Patterns, The Rutgers University Press, I968, in the press.

7 H. N. Christensen, Ann. Rev. Biochem., 22 (I953) 233.

8 D. E. Boggs and C. M. McKean, Federation Proc., 24 (Ig65) 3 I6.

9 C. M. McKean and W. DeRafols, Federation Proc., 25 (I966) 364.

io D. L. Oxender and H. N. Christensen, J. Biol. Chem., 238 (I963) 3686.

i i H. N. Christensen and M. Liang, J. Biol. Chem., 240 (I965) 360 I.

i 2 H. Akedo and H. N. Christensen, J. Biol. Chem., 237 (I962) i I 3.

I 3 S. Gabriel, Ber. Deut. Chem. Ges., 47 (I9I4) 2922.

I4 S. Gabriel, Ber. Deut. Chem. Ges., $4^{6}$ (r9i3) I319. 
I 5 N. Zelinsky and G. STadnikoff, Ber. Deut. Chem. Ges., 39 (I906) I 722.

I6 R. ScharfF AND I. G. WoOL, Nature, 202 (1964) 603.

I 7 D. H. Spackman, S. Moore and W. D. Stein, Anal. Chem., 30 (1904) 374.

I8 H. N. Christensen and J. C. Jones, J. Biol. Chem., 237 (1962) Izo3.

I9 T. R. RigGS AND L. M. WALKER, Endocrinology, 73 (I963) 78 I.

20 K. LANG AND H. OSTER, Biochem. Z., 324 (1953) 443.

2 I H. B. Lewis, Yale J. Biol. Med., 4 (I932) 437.

22 E. M. Wise, Jr. And D. Elwyn, Proc. Soc. Expll. Biol. Med., I2 I (1966) 982.

23 H. N. Christensen, M. Liang and E. G. ArCher, J. Biol. Chem., 242 (1967) 5237.

24 H. N. Christensen, D. L. Oxender, M. Liang and K. A. Vatz, J. Biol. Chem., 240 (ig65) 3609.

25 A. J. Clark, O. Matsutani and M. E. Swenseid, Federation Proc., 26 (Ig67) 522.

26 R. R. BRown, Science, I57 (1967) 432.

27 W. A. Webber, Can. J. Physiol. Pharmacol., 44 (I966) 507.

28 N. H. Christensen and M. Liang, J. Biol. Chem., 24 I (I966) 5542.

29 C. E. Dent, B. Senior and J. M. Walshe, J. Clin. Invest., 33 (1954) I 26.

30 G. S. Robson and G. A. Rose, Clin. Sci., i6 (r957) 75 .

3I L. E. Rosenberg, S. J. Downing and S. Segal, J. Biol. Chem., 237 (Ig62) 2265.

32 L. E. Rosenberg, S. Downing, J. L. Durant and S. Segal, J. Clin. Invest., 45 (I966) 365.

33 L. Schwartzman, A. Blair and S. Segal, Biochem. Biophys. hes. Commun., 23 (I966) 220.

34 W. A. WebBer, Am. J. Physiol., 202 (I962) 577.

35 B. G. Munck, Biochim. Biophys. Acta, I 20 (1966) 282.

36 C. R. Scriver, M. L. Efron and I. A. Schafer, J. Clin. Invest., 43 (1964) 374.

37 H. Hagahira, T. H. Wilson and E. C. C. Lin, Am. J. Physiol., 203 (Ig62) 637.

38 H. Schimassek AND W. Gerok, Biochem. $Z$., 343 (I965) 407.

Biochim. Biophys. Acta, I $5^{\circ}$ (1968) $237^{-2} 5^{2}$ 